\title{
Why unprecedented ozone loss in the Arctic in 2011? Is it related to climate change?
}

\author{
J.-P. Pommereau ${ }^{1}$, F. Goutail ${ }^{1}$, F. Lefèvre ${ }^{1}$, A. Pazmino ${ }^{1}$, C. Adams $^{6}$, V. Dorokhov ${ }^{2}$, P. Eriksen ${ }^{3}$, R. Kivi ${ }^{4}$, K. Stebel ${ }^{5}$, \\ X. Zhao ${ }^{6}$, and M. van Roozendael ${ }^{7}$ \\ ${ }^{1}$ LATMOS, UMR8190, CNRS-Université de Versailles St Quentin, Guyancourt, France \\ ${ }^{2}$ Central Aerological Observatory, Dolgoprudny, Russia \\ ${ }^{3}$ Danish Meteorological Institute, Copenhagen, Denmark \\ ${ }^{4}$ Finnish Meteorological Institute, Sodankylä, Finland \\ ${ }^{5}$ Norwegian Institute for Air Research, Kjeller, Norway \\ ${ }^{6}$ Department of Physics, University of Toronto, Toronto, Ontario, Canada \\ ${ }^{7}$ Belgian Institute for Space Aeronomy (IASB-BIRA), Brussels, Belgium
}

Correspondence to: J.-P. Pommereau (pommereau@aerov.jussieu.fr)

Received: 24 October 2012 - Published in Atmos. Chem. Phys. Discuss.: 7 January 2013

Revised: 16 April 2013 - Accepted: 26 April 2013 - Published: 27 May 2013

\begin{abstract}
An unprecedented ozone loss occurred in the Arctic in spring 2011. The details of the event are revisited from the twice-daily total ozone and $\mathrm{NO}_{2}$ column measurements of the eight SAOZ/NDACC (Système d'Analyse par Observation Zénithale/Network for Detection of Atmospheric Composition Changes) stations in the Arctic. It is shown that the total ozone depletion in the polar vortex reached $38 \%$ (approx. $170 \mathrm{DU}$ ) by the end of March, which is larger than the $30 \%$ of the previous record in 1996. Aside from the long extension of the cold stratospheric NAT PSC period, the amplitude of the event is shown to be resulting from a record daily total ozone loss rate of $0.7 \% \mathrm{~d}^{-1}$ after mid-February, never seen before in the Arctic but similar to that observed in the Antarctic over the last $20 \mathrm{yr}$. This high loss rate is attributed to the absence of $\mathrm{NO}_{\mathrm{x}}$ in the vortex until the final warming, in contrast to all previous winters where, as shown by the early increase of $\mathrm{NO}_{2}$ diurnal increase, partial renoxification occurs by import of $\mathrm{NO}_{\mathrm{x}}$ or $\mathrm{HNO}_{3}$ from the outside after minor warming episodes, leading to partial chlorine deactivation.

The cause of the absence of renoxification and thus of high loss rate, is attributed to a vortex strength similar to that of the Antarctic but never seen before in the Arctic. The total ozone reduction on 20 March was identical to that of the 2002 Antarctic winter, which ended around 20 September, and a 15-day extension of the cold period would have been
\end{abstract}

enough to reach the mean yearly amplitude of the Antarctic ozone hole. However there is no sign of trend since 1994, either in PSC (polar stratospheric cloud) volume (volume of air cold enough to allow formation of PSCs), early winter denitrification, late vortex renoxification, and vortex strength or in total ozone loss. The unprecedented large Arctic ozone loss in 2011 appears to result from an extreme meteorological event and there is no indication of possible strengthening related to climate change.

\section{Introduction}

An unprecedented stratospheric ozone loss has been reported in the Arctic by ground-based, sonde and satellites observations during the winter 2010-2011 (Manney et al., 2011; Sinnhuber et al., 2011; Arnone et al., 2012; Lindenmaier et al., 2012; Adams et al., 2012). It was mainly attributed to unusually long-lasting cold stratospheric conditions allowing Polar Stratospheric Clouds (PSCs) to form until late March. Chlorine activation and ozone loss was found comparable to that in the Antarctic ozone hole. But the warmer conditions, the lesser removal of nitric acid by denitrification and the absence of dehydration, suggest that Arctic ozone holes are possible even with temperature much milder than those in the Antarctic (Manney et al., 2011; Arnone et al., 2012; 
Sinnhuber et al., 2011). Although it has been suggested that cold winters have been getting colder during the last four decades (Rex et al., 2004), consistent with the global cooling of the middle and upper stratosphere predicted by chemistryclimate models due to the greenhouse gases increase (WMO, 2011), and a possible large depletion in case of unusually cold winter recognised for long (WMO, 2011), the eventuality of such extreme loss was unpredicted. On the contrary, climate models are suggesting a progressive decrease of ozone depletion following the global reduction of concentration of ozone depleting substances (ODS), faster in the Arctic than in the Antarctic because of the warmer northern winter stratosphere (WMO, 2011). The question is thus to understand the reason for the unprecedented ozone loss in 2011, why it did not happen earlier and if it could happen again. For better understanding the details of the event, the time evolutions of ozone and $\mathrm{NO}_{2}$ during the winter are examined from the twice-daily measurements of the eight Arctic stations of the SAOZ/NDACC (Système d'Analyse par Observation Zénithale/Network for Detection of Atmospheric Composition Changes) UV-Vis spectrometer network. Section 2 describes the evolution of the loss during the winter and its relationship with stratospheric temperature, PSCs, denitrification and chlorine activation. The 2011 event is discussed by comparison to losses observed in the Arctic since 1994 in Sect. 3 and in the Antarctic in Sect. 4. The results are summarised in Sect. 5 .

\section{How much ozone loss in and out vortex in 2011}

The ozone loss is determined by the "passive ozone" method, in which the total ozone columns measured by the SAOZ/NDACC UV-Vis spectrometer stations are compared to the "passive" ozone column predicted by a chemistrytransport model in the absence of chemistry (Goutail et al., 1999).

\subsection{Tools}

The data are those of eight SAOZ stations distributed around the Arctic (Table 1) providing measurements at solar zenith angle (SZA) up to $91^{\circ}$, that is, throughout all the winter at the polar circle, but only after the return of the sun at higher latitude (Pommereau and Goutail, 1988). Total ozone is retrieved in the visible Chappuis bands (version V2 retrieval algorithm, precision $4.5 \%$, total accuracy $5.9 \%$ ) with the spectral analysis and air mass factor (AMF) settings recommended by the NDACC UV-Vis Working Group (Hendrick et al., 2011). The ozone columns used are sunrise-sunset means. $\mathrm{NO}_{2}$ morning and evening columns are available with $10-15 \%$ accuracy.

The ozone loss is derived by comparison with the ozone columns of the REPROBUS chemistry transport model (CTM) (Lefèvre et al., 1994) run in passive mode without
Table 1. SAOZ Arctic stations, latitude, longitude and date of start.

\begin{tabular}{lll}
\hline Eureka, Nunavut & $80^{\circ} \mathrm{N}, 86^{\circ} \mathrm{W}$ & 2006 \\
Ny-Alesund, Svalbard & $78^{\circ} \mathrm{N}, 12^{\circ} \mathrm{E}$ & 1991 \\
Thule, Greenland & $76^{\circ} \mathrm{N}, 69^{\circ} \mathrm{W}$ & 1991 \\
Scoresbysund, Greenland & $71^{\circ} \mathrm{N}, 22^{\circ} \mathrm{W}$ & 1991 \\
Sodankylä, Finland & $67^{\circ} \mathrm{N}, 27^{\circ} \mathrm{E}$ & 1990 \\
Salekhard, Russia & $67^{\circ} \mathrm{N}, 67^{\circ} \mathrm{E}$ & 1998 \\
Zhigansk, Russia & $67^{\circ} \mathrm{N}, 123^{\circ} \mathrm{E}$ & 1992 \\
Harestua, Norway & $60^{\circ} \mathrm{N}, 11^{\circ} \mathrm{E}$ & 1994 \\
\hline
\end{tabular}

chemistry. Winds and temperatures used to drive the CTM are those of the ECMWF ERA-Interim reanalyses (Simmons et al., 2006). REPROBUS was initialised on 1 December 2010 and was integrated on 60 vertical levels from the surface to $0.1 \mathrm{hPa}$, with a horizontal resolution of $2^{\circ} \times 2^{\circ}$. The passive mode of REPROBUS has no chemical component and considers only a single "passive ozone" tracer. This tracer is initialised identically to the ozone analysed by ECMWF at the beginning of the simulation and is then transported by the winds without any chemical production or loss. This allows for a diagnosis of the ozone chemical loss by making the difference between the "passive ozone" column calculated every day by the model over each station and the ozone column measured by SAOZ. In addition, a REPROBUS "gas phase" simulation with full chemistry but without heterogeneous processes is carried out to quantifying the contribution of gas-phase chemistry (without PSCs) to the observed ozone loss. The "gas phase" simulation employs the comprehensive chemical package of REPROBUS, with 45 species and 120 reactions and photolytic processes. Absorption cross-sections and kinetics data for this run are all based on the latest JPL compilation (Sander et al., 2011).

The location of the station in reference to the vortex is provided by the potential vorticity $(\mathrm{PV})$ on isentropic surfaces calculated by the MIMOSA contour advection model (Hauchecorne et al., 2002), where the vortex edge is defined as the maximum PV gradient (Nash et al., 1996)

\subsection{Ozone loss over Sodankylä}

As an example, Fig. 1 shows the analysis of the SAOZ ozone and $\mathrm{NO}_{2}$ measurements in Sodankylä in Northern Finland from 1 December 2010 until 15 April 2011. During the darkest period until about 15 January, there is no difference (inside or outside of the vortex) between "passive", "gas phase", and SAOZ ozone columns. The $\mathrm{NO}_{2}$ column is small with no diurnal variation, but shows some sporadic spikes due to tropospheric pollution from Central and Western Europe transported during surface, high south wind episodes (Pommereau and Goutail, 1988). The further evolution is significantly different inside and outside of the vortex. Outside of the vortex, the difference between SAOZ and passive ozone columns builds up after mid-January, reaching about $40 \mathrm{DU}(10 \%)$ at 


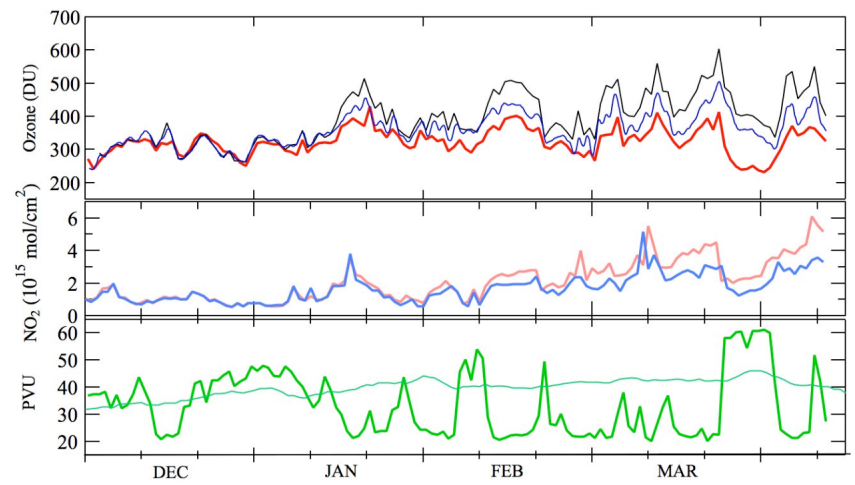

Fig. 1. SAOZ measurements in Sodankylä from 1 December 2010 to 15 April 2011. From top to bottom: SAOZ total ozone (red) compared to REPROBUS passive ozone (black) and gas-phase chemistry only (blue); $\mathrm{SAOZ} \mathrm{NO}_{2}$ column (sunrise blue, sunset red); and potential vorticity at $475 \mathrm{~K}$ (green) and limit of the vortex (thin line).

the end of March. Inside the vortex, the difference reaches 50 DU (12\%) around February 10 and 170 DU (40\%) in late March. However, according to the model $12 \%$ (about $50 \mathrm{DU}$ ) would be due to gas-phase chemistry only, leaving $26 \%$ (120 DU) only to depletion by activated chlorine. Aside from sporadic tropospheric pollution episodes, $\mathrm{NO}_{2}$ shows smaller columns and diurnal increase inside than outside the vortex. Since the spring increase of $\mathrm{NO}_{\mathrm{x}}$ concentration originates from the photolysis of $\mathrm{HNO}_{3}$, those features are indicative of strong denitrification $\left(\mathrm{HNO}_{3}\right.$ removal by sedimentation of nitric acid rich NAT particles) in the vortex.

\subsection{Mean ozone loss and denitrification in and out vortex}

The mean ozone loss is given by the 10-day average difference between $\mathrm{SAOZ}$ and passive ozone columns above the eight SAOZ stations as represented in Figs. 2 and 3 for inside and outside the vortex, respectively. Also shown in the figures are the $\mathrm{NO}_{2}$ sunrise and sunset columns above the same stations.

The ozone depletion diagnosed in the vortex shows two phases: an early loss that reaches $11 \%$ on February 10 at an average rate of $0.2 \% \mathrm{~d}^{-1}$, followed by 40 days until March 20 of faster depletion at an average rate of $0.7 \%$ day $^{-1}$. The first phase corresponds to the period of low solar illumination and inhomogeneous loss in the vortex when the depletion is restricted to a ring area at the inner edge (Goutail et al., 2005). The loss derived from each station is thus very dependent on its location relative to the centre of the vortex, resulting in a large dispersion between individual measurements. During the second phase, when the sun reaches SAOZ stations at higher latitude and the measurements are closer from the center of the vortex, the amount of data increases and the loss becomes more homogeneous. The total ozone loss in the vortex calculated at the end of the winter

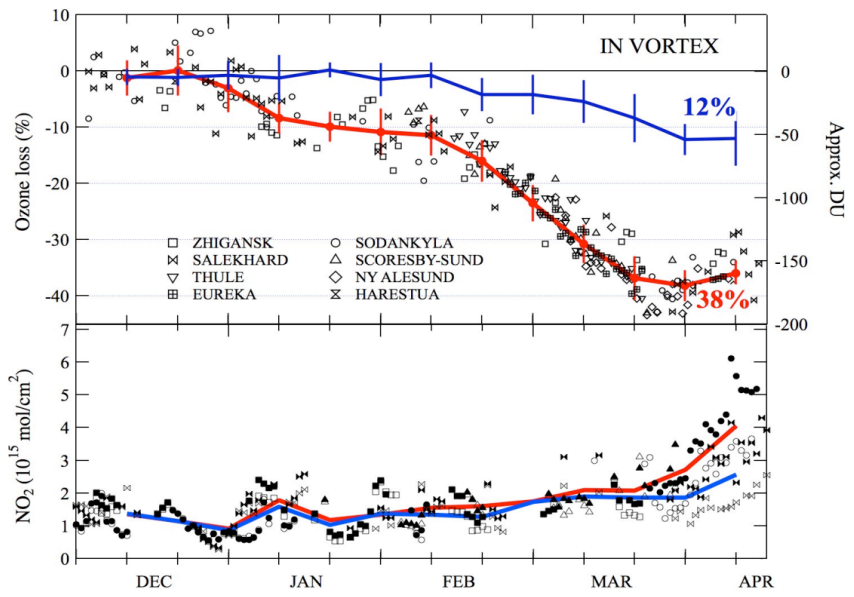

Fig. 2. Ozone loss (top) and total $\mathrm{NO}_{2}$ (bottom) in the vortex. The ozone loss is given by the difference between SAOZ and passive ozone columns where markers are representing the loss above each station and the red line 10-day averages with dispersion. The blue line is the difference between passive ozone and gas phase REPROBUS simulations. A $12 \%$ total loss at an average rate of $0.2 \%$ day $^{-1}$ is observed between 20 December and 10 February, followed by a faster depletion at $0.7 \%$ day $^{-1}$ until 20 March. The total loss at the end of the winter compared to a pure ozone tracer reaches $38 \pm 5 \%$ and $26 \%$ compared to the gas phase simulation. The evolution of the $\mathrm{NO}_{2}$ column in the bottom panel (open markers and blue line at sunrise, filled markers and red line at sunset) is showing low values until mid-March, increasing rapidly after. The amplitude of the $\mathrm{NO}_{2}$ diurnal cycle remains limited until 20 March and enhances rapidly after.

is $38 \pm 5 \%$ (approx. $170 \mathrm{DU}$ ), among which $12 \%$ (50 DU) would be due to gas-phase chemistry. Most of the ozone loss diagnosed by the gas-phase only simulation can be attributed to $\mathrm{NO}_{\mathrm{x}}$-driven cycles that from mid-March 2011 are dominating the $\mathrm{O}_{3}$ loss at upper levels, as shown at $675 \mathrm{~K}$ by Kuttippurath et al. (2012). This latter study also showed that the net $\mathrm{O}_{3}$ loss at $675 \mathrm{~K}$ was larger than in previous cold Arctic winters. Considering the fact that most of the $\sim 50 \mathrm{DU}$ gasphase loss occurs above $550 \mathrm{~K}$, the $\sim 170 \mathrm{DU}$ total loss over the whole vertical column diagnosed here is consistent with the 120 DU loss calculated by Sinnhuber et al. (2011) over the smaller $380-550 \mathrm{~K}$ interval.

In contrast, outside the vortex (Fig. 3), the ozone chemical loss starts in early January at a mean rate of $0.2 \%$ day $^{-1}$. The accumulated loss shows a total ozone reduction of about $20 \%$ ( $80 \mathrm{DU}$ ) by mid-April, entirely attributed to gas-phase chemistry by the model. This loss is larger than the gas-phase loss inside of the vortex because of the larger $\mathrm{HOx}-\mathrm{NO}_{\mathrm{x}}$ concentration, the higher sun and longer day. There is no indication there of a significant contribution from activated halogens or export of depleted air masses.

The $\mathrm{NO}_{2}$ columns shown in Figs. 2 and 3 are restricted to polar circle latitude stations to avoid the latitude dependent duration of the day and noontime SZA. Aside from the 


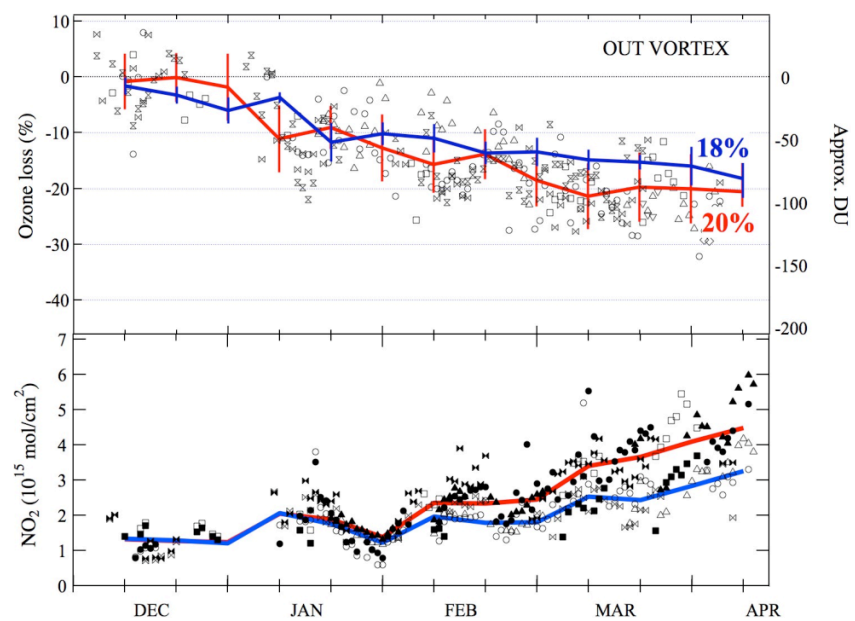

Fig. 3. Same as Fig. 2 but outside the vortex. The ozone depletion derived from the difference between $\mathrm{SAOZ}$ and passive ozone is very similar to that simulated by the model in gas-phase chemistry only. There is no indication of significant contribution from heterogeneous chlorine activation or export of depleted ozone from the vortex. The $\mathrm{NO}_{2}$ column and its diurnal variation begin to increase in early February, one and a half months sooner than in the inside.

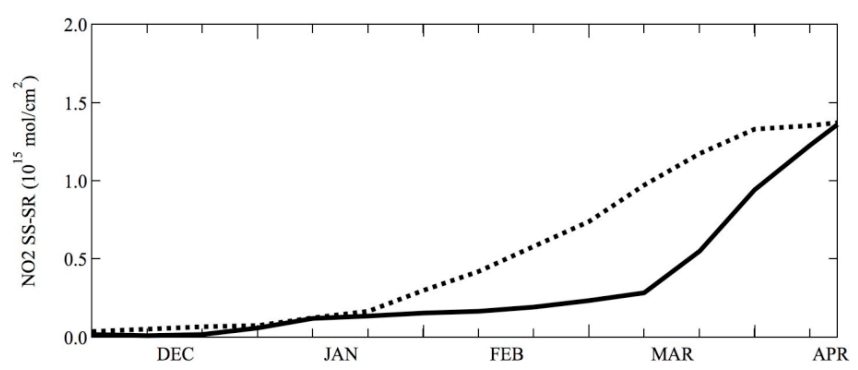

Fig. 4. Amplitude of the $\mathrm{NO}_{2}$ diurnal cycle inside (solid line) and outside (dotted line) the vortex.

noise due to pollution episodes, particularly in Sodankylä and Salekhard, the picture is significantly different in the inside and the outside of the vortex. In the inside (bottom panel of Fig. 2) the $\mathrm{NO}_{2}$ column is low until mid-March, followed by a rapid growth of both total amounts and diurnal cycle amplitude. In contrast, outside the vortex (bottom panel of Fig. 3) the $\mathrm{NO}_{2}$ columns and the amplitude of the diurnal variation increase sooner, in early February. The best indicator of this difference, less sensitive to tropospheric pollution episodes, is the amplitude of the $\mathrm{NO}_{2}$ diurnal cycle shown in Fig. 4. The late increase of its amplitude inside the vortex, compared to earlier increase in the outside, is an indication of the absence of $\mathrm{NO}_{\mathrm{x}}$ species, implying a large removal of $\mathrm{HNO}_{3}$ and a delayed formation of $\mathrm{ClONO}_{2}$ and thus chlorine deactivation inside the vortex as reported by MLS/AURA (Manney et al., 2011), MIPAS/ENVISAT (Arnone et al., 2012; Sinnhuber et al., 2011) and the groundbased FTIR in Eureka (Lindenmaier et al., 2012).

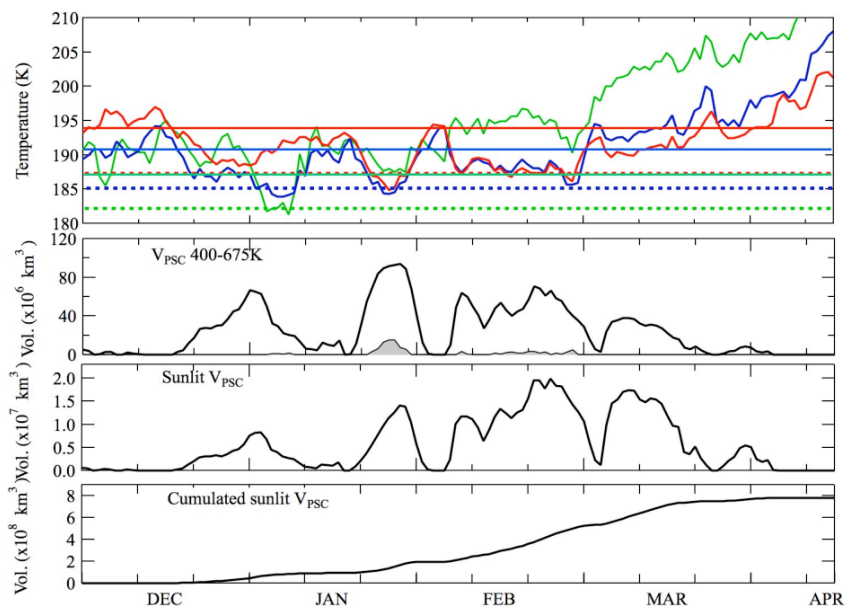

Fig. 5. Top: ECMWF ERA-Interim minimum temperature north of $60^{\circ} \mathrm{N}$ at $475 \mathrm{~K}$ (red), $550 \mathrm{~K}$ (blue) and $675 \mathrm{~K}$ (green) and NAT (solid lines) and ICE (dotted) threshold temperatures at the same levels. Bottom panels: PSC volume between 400-675 K, from top to bottom: (i) total volume below $T_{\mathrm{NAT}}$ (solid line) and $T_{\mathrm{ICE}}$ (grey area); (ii) sunlit $\left(\mathrm{SZA}<93^{\circ}\right)$ PSC volume indicative of chlorine activation; and (iii) integrated sunlit $V_{\mathrm{PSC}}$.

\subsection{Relation with temperature, denitrification and chlorine activation}

Displayed in Fig. 5 are the minimum ERA-Interim temperatures poleward of $60^{\circ} \mathrm{N}$ at 475,550 and $675 \mathrm{~K}$, with the NAT threshold temperature formation $\left(T_{\mathrm{NAT}}\right)$ at the same levels. $T_{\mathrm{NAT}}$ is calculated from the formula of Hanson and Mauersberger (1988) and the MIPAS water vapour and nitric acid measurements in March 2011 (Arnone et al., 2012). As shown in Table 2, $T_{\mathrm{NAT}}$ was colder in March 2011 than the previous winters average by $1 \mathrm{~K}$ at 475 and $550 \mathrm{~K}$ because of the $2 \mathrm{ppb}$ lower $\mathrm{HNO}_{3}$ concentration. NAT PSCs were thermodynamically possible from mid-December onwards at all levels, extending until early March at $675 \mathrm{~K}$, mid-March at $550 \mathrm{~K}$ and late March at $475 \mathrm{~K}$. Remarkable are the extremely low temperatures at higher levels $(181 \mathrm{~K}$ at $550 \mathrm{~K}$, $178 \mathrm{~K}$ at $675 \mathrm{~K}$ ) in early January where high-altitude PSCs were observed by MIPAS (Arnone et al., 2012) followed by several periods of temperature below $T_{\mathrm{NAT}}$ at 475 and $550 \mathrm{~K}$ separated by minor warming episodes in mid-January and early February, resulting in deep denitrification as reported by MIPAS and MLS (Arnone et al., 2012; Manney et al., 2011).

Also displayed in Fig. 5 are (i) the potential volume of NAT PSCs ( $V_{\text {PSC }}$ ) between 400 and $675 \mathrm{~K}(13.5-25.5 \mathrm{~km})$, a proxy for chlorine activation; (ii) the volume of sunlit NAT PSCs (sunlit $V_{\mathrm{PSC}}$ ) weighted by the ratio between sunlit $\left(\mathrm{SZA}<93^{\circ}\right)$ and total vortex surface, a proxy of $\mathrm{ClO}$ photochemistry volume; and (iii) the integrated weighted sunlit $V_{\text {PSC }}$ since the beginning of the winter. According to ERAInterim temperatures, PSCs could have formed and chlorine 
Table 2. Threshold temperature of NAT and ICE formation calculated for March 2011 and Arctic mean from monthly average $\mathrm{HNO}_{3}$ and $\mathrm{H}_{2} \mathrm{O}$ concentrations reported by MIPAS (Arnone et al., 2012).

\begin{tabular}{cccccccc}
\hline Theta & Alt. & $\mathrm{H}_{2} \mathrm{O}$ & $\begin{array}{c}\mathrm{HNO}_{3} \\
2011 \\
(\mathrm{ppb})\end{array}$ & $\begin{array}{c}T_{\mathrm{NAT}} \\
(\mathrm{K})\end{array}$ & $\begin{array}{c}\mathrm{HNO}_{3} \\
\mathrm{Mean} \\
(\mathrm{ppb})\end{array}$ & $\begin{array}{c}T_{\mathrm{NAT}} \\
\text { Mean } \\
(\mathrm{K})\end{array}$ & $\begin{array}{c}T_{\mathrm{ICE}} \\
(\mathrm{K})\end{array}$ \\
\hline 475 & 20.2 & 4.6 & 6 & 194 & 8 & 195 & 187 \\
550 & 23.7 & 5.0 & 6 & 191 & 8 & 192 & 185 \\
675 & 28.5 & 5.5 & 5 & 187 & 5 & 187 & 182 \\
\hline
\end{tabular}

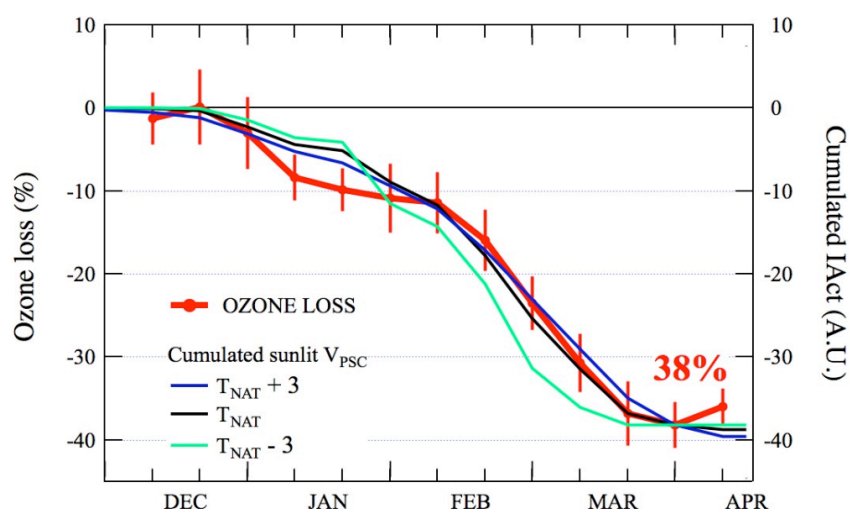

Fig. 6. $\mathrm{O}_{3}$ loss and vortex sunlit-weighted PSC cumulated volume calculated for $T_{\mathrm{NAT}}-3 \mathrm{~K}$ (green), $T_{\mathrm{NAT}}$ (black) and $T_{\mathrm{NAT}}+3 \mathrm{~K}$ (blue) normalised on 30 March.

activated first in late December and early January at high altitude up to $675 \mathrm{~K}$. Later on they were present during the whole winter but at 475 and $550 \mathrm{~K}$ only after early February and at $475 \mathrm{~K}$ only after mid-March, but almost absent during four minor warming episodes in mid-January, in early February and late March. Among all these most sunlit PSCs, the best proxy for ozone depleting photochemistry, occurred between mid-February to mid-March. The question is which type of PSC is responsible for chorine activation and ozone loss. Figure 6 compares the ozone loss of Fig. 2 to the integrated sunlit $V_{\mathrm{PSC}}$, assuming that activation occurs at $T_{\mathrm{NAT}}-3 \mathrm{~K}, T_{\mathrm{NAT}}$ and $T_{\mathrm{NAT}}+3 \mathrm{~K}$. Although $V_{\mathrm{PSC}}$ increases from 0.1 to 0.6 and $1.45 \times 10^{9} \mathrm{~km}^{3}$ at increasing threshold temperature, to better understand the relationship between the time evolution of PSC and ozone loss, $V_{\mathrm{PSC}}$ has been normalised at the date of the end of the ozone destruction on 30 March. $V_{\mathrm{PSC}}$ at $T_{\mathrm{NAT}^{-}}$ $3 \mathrm{~K}$ correspond to supercooled ternary solution (STS) (Stein et al., 1999) reduces rapidly after mid-February, resulting in an end of $\mathrm{O} 3$ loss 15 days earlier than observed. At the opposite end, $T_{\mathrm{NAT}}+3 \mathrm{~K}$ would delay it by 10 days. The best match is with PSC forming at $T_{\mathrm{NAT}}$. Unless the ERA-Interim temperatures are biased, the observed ozone loss is fully consistent with chlorine, remaining activated until temperature remains below $T_{\mathrm{NAT}}$ stops (i.e. at temperature below $194 \mathrm{~K}$ at $50 \mathrm{hPa}$, approx. $19 \mathrm{~km}$ or $475 \mathrm{~K}$ ).

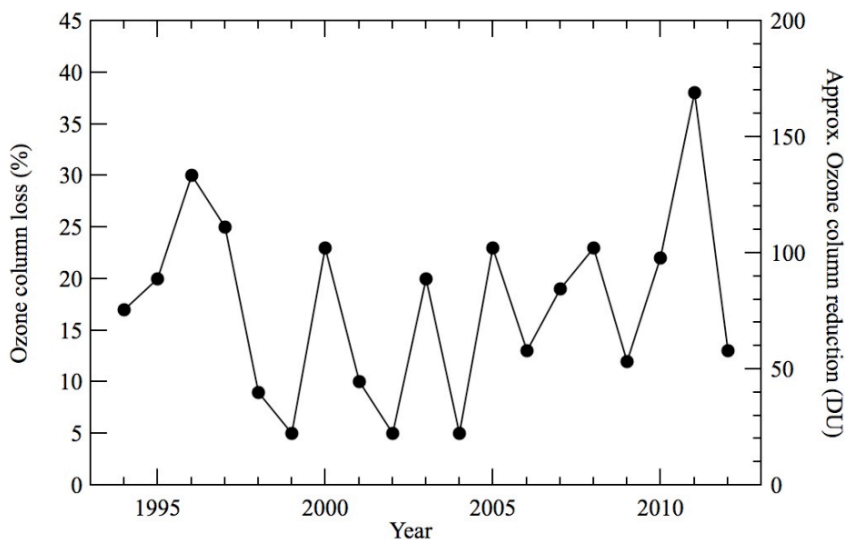

Fig. 7. Yearly ozone loss in the Arctic since 1994 derived from the measurements of the SAOZ/NDACC stations by the passive ozone method revisited using ERA-Interim reanalyses.

\section{Comparison with previous winters}

The SAOZ/NDACC Arctic network has been providing daily ozone and $\mathrm{NO}_{2}$ measurements since 1994 from which the relationship between ozone loss, denitrification and PSC volume calculated from the ERA-Interim temperatures can be investigated.

\subsection{Ozone Loss}

Figure 7 shows the total ozone loss derived from the SAOZ Arctic stations since 1994. For the sake of homogeneity, this analysis uses the ECMWF ERA-Interim reanalyses for all years instead of the operational analyses used in previous publications (WMO, 2007). Significant changes are observed in the difference of temperature in the vortex between ERAInterim and operational analysis. Indeed, operational analyses moved in late 1997 from a 31-level 3-D variational assimilation to a 50-level 4-D variational scheme including assimilation of the AMSU data, followed by a further change to 60-level in late 1999. When compared to the temperatures measured in the vortex by long-duration balloon between $30-146 \mathrm{hPa}$, operational temperatures showed insignificant bias of $+0.33 \pm 1.37 \mathrm{~K}$ in 1997 , dropping to $-0.49 \pm 0.91 \mathrm{~K}$ in 2000 (Pommereau et al., 2002; Knudsen et al., 2002). The difference between ERA-Interim and operational analysis summarised in Table 3 suggests that operational analyses might be cold biased by $1-3 \mathrm{~K}$ depending on the year and altitude level.

The largest losses occurred in 1996 (30\%), 1997 (25\%), $2000(23 \%), 2003(20 \%), 2005(23 \%), 2008(23 \%)$ and $2011(38 \%)$. There has been no trend since 1994 other than high inter-annual variability in the depletion. Remarkably, the loss is never zero, even during years when little PSCs formed or when the vortex ended in January like in 1999, 2002 and 2004. The minimum $5 \%$ depletion observed even in those years is consistent with an ozone reduction caused by 

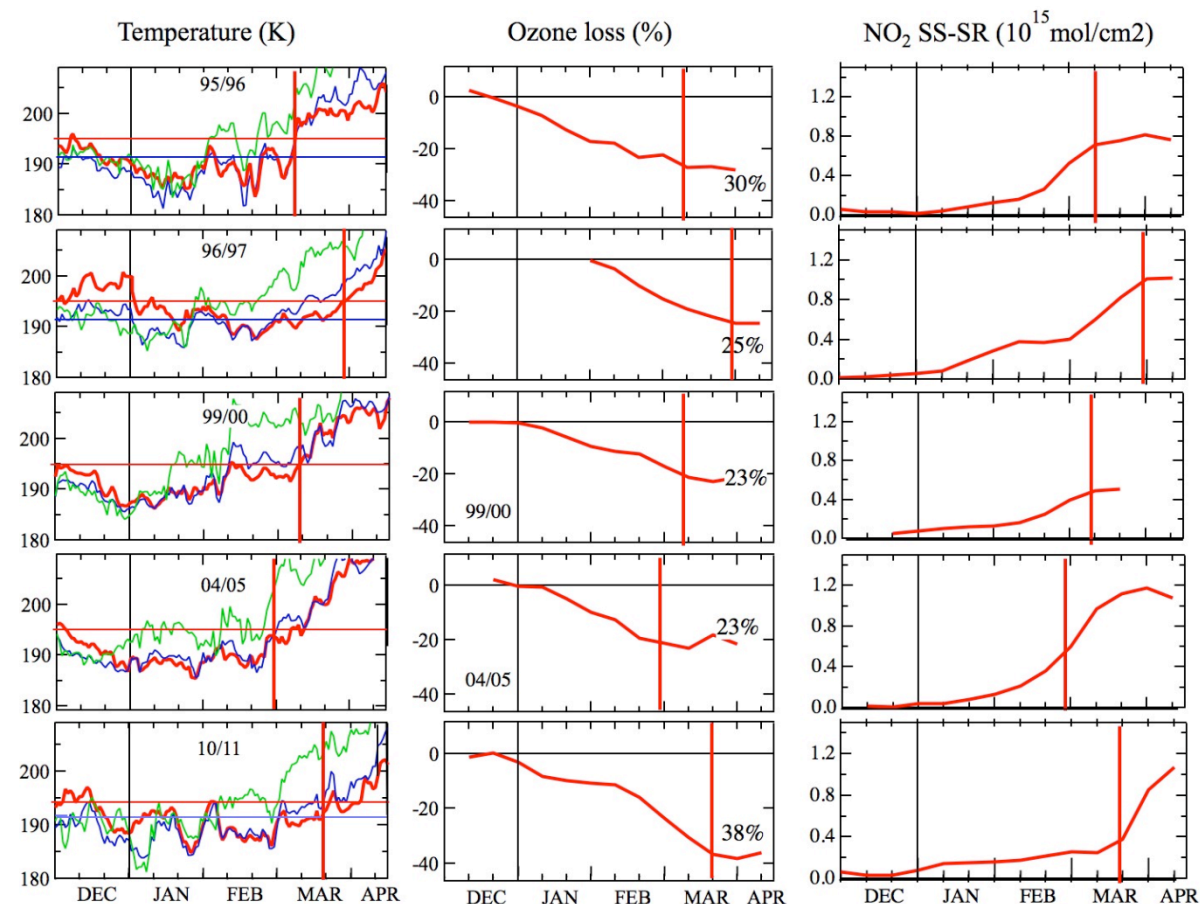

Fig. 8. Temperature, ozone loss and $\mathrm{NO}_{2}$ diurnal variation during years of most important loss in the Arctic since 1994. Left: ERA-Interim minimum temperature north of $60^{\circ} \mathrm{N}$ at $475 \mathrm{~K}$ (red), $550 \mathrm{~K}$ (blue) and $675 \mathrm{~K}$ (green) and respective $T_{\mathrm{NAT}}$. Middle: SAOZ ozone loss. Right: SAOZ $\mathrm{NO}_{2}$ diurnal cycle amplitude. Shown by the vertical red bars are the dates of final warming. From top to bottom: 1995-1996, 1996-1997, 1999-2000, 2004-2005 and 2010-2011.

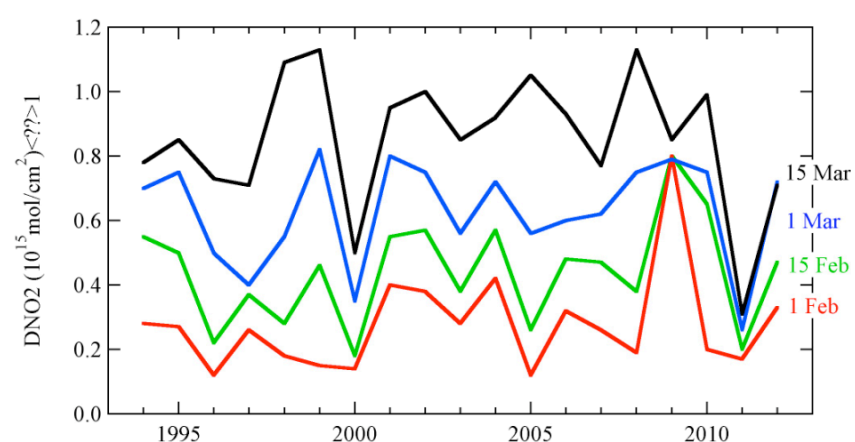

Fig. 9. $\mathrm{NO}_{2}$ diurnal variation amplitude each year on 1 February, 15 February, 1 March and 15 March. Although large denitrification is frequent in early winter such as in 1996, 2000, 2005, 2008, 2010 and 2011, it is generally followed by fast renoxification during the following weeks. 2000 and 2011 are the only years of low $\mathrm{NO}_{\mathrm{x}}$ until early March, 2011 being the year of longest denitrification.

gas-phase chemistry at high altitude of amplitude depending on the dynamics of each winter as explained by Kuttippurath et al. (2012).

\subsection{Ozone loss rate and denitrification}

Figure 8 shows the detail of the evolution of temperature, ozone loss and $\mathrm{NO}_{2}$ diurnal increase for the five years of largest ozone depletion. Among the five, 1997 was that of the longest stratospheric winter, ending around March 30, and 1996 that of the largest depletion after 2011. But the most remarkable difference between 2011 and all other years is the fastest ozone loss rate of $0.7 \% \mathrm{~d}^{-1}$ after 10 February, compared to a maximum $0.35 \%-0.45 \% \mathrm{~d}^{-1}$ on all other years, even during sunlit March. Another unique characteristic of 2011, consistent with this fast depletion rate, is the late increase of the $\mathrm{NO}_{2}$ diurnal cycle that is the absence of $\mathrm{NO}_{\mathrm{x}}$ and thus of chlorine deactivation until the final warming. This is in contrast with all previous years when the $\mathrm{NO}_{\mathrm{x}}$ concentration started increasing well before the final warming. In 1996, the onset of the diurnal cycle of $\mathrm{NO}_{2}$ occurred around 20 February, i.e. 20 days before the end of the ozone depletion period. In 1997, the year of the longest winter, it started around 20 January and amplified rapidly after 1 March, that is, one month before the final warming. This fast increase of $\mathrm{NO}_{2}$ is confirmed by measurements from long-duration balloons navigating in the vortex (Denis et al., 2000). After 2011, the year of latest $\mathrm{NO}_{2}$ diurnal increase is 2000 .

A major difference between 2011 and previous winters, is thus the amount of $\mathrm{NO}_{\mathrm{x}}$ available, the rate-limiting step of chlorine deactivation by formation of $\mathrm{ClONO}_{2}$ (Harris et al., 2010), confirmed by the late growth of $\mathrm{ClONO}_{2}$ concentration at the $450 \mathrm{~K}$ reported by MIPAS after March 20 only in 2011 (Arnone et al., 2012). These late denitrification 


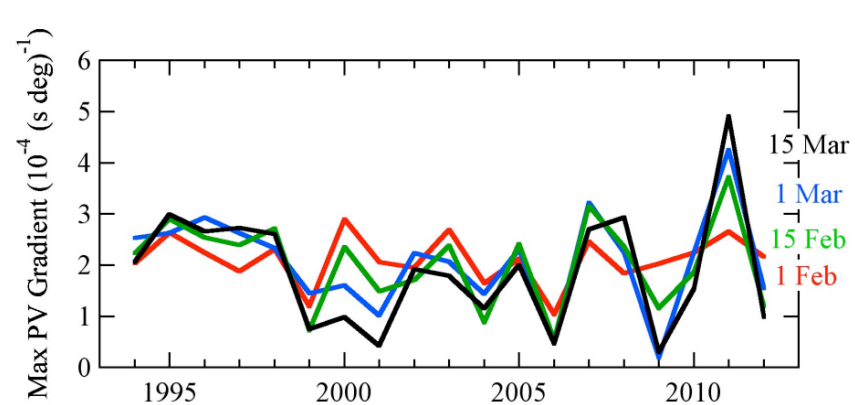

Fig. 10. Maximum PV gradient at $475 \mathrm{~K}$ indicative of vortex strength. The 2011 vortex was stronger than all others after midFebruary.

Table 3. ERA-Interim-ECMWF operational analyses mean difference of minimum temperature poleward of $60^{\circ} \mathrm{N}$ in the winter between 1994 and 2012.

\begin{tabular}{ccc}
\hline Year & $\Delta T 475 \mathrm{~K}$ & $\Delta T 550 \mathrm{~K}$ \\
\hline 1994 & 0 & 0 \\
1995 & 0 & 0 \\
1996 & 0 & 0 \\
1997 & 0 & 0 \\
1998 & 0 & 2.6 \\
1999 & 0 & 3.6 \\
2000 & 1.0 & 2.0 \\
2001 & 0 & 3.4 \\
2002 & 0.8 & 2.6 \\
2003 & 1.6 & 3.0 \\
2004 & 1.7 & 1.0 \\
2005 & 1.9 & 1.7 \\
2006 & 2.4 & 1.7 \\
2007 & 1.3 & 2.1 \\
2008 & 2.1 & 2.6 \\
2009 & 1.6 & 1.8 \\
2010 & 2.3 & 2.3 \\
2011 & 2.4 & 1.8 \\
2012 & 0.5 & 0.9 \\
\hline
\end{tabular}

and chlorine deactivations are confirmed by the unusually low $\mathrm{HNO}_{3}$ concentration and the large $\mathrm{ClO}$ amount at $485 \mathrm{~K}$, seen by MLS until late March, similar to that observed in the Antarctic in September (Manney et al., 2011). Apart from the long duration of the cold stratospheric winter, the explanation for the record ozone depletion in the Arctic in 2011 is thus the fast loss rate after 10 February until the final warming because of the unprecedented late renoxification and chlorine deactivation.

Figure 9 shows the amplitude of the $\mathrm{NO}_{2}$ diurnal cycle, a proxy for denitrification, for each year on 1 February, 15 February, 1 March and 15 March since 1994. The 2011 denitrification on 1 February is similar to that observed in other cold early winters such as 1995/1996, 1999/2000, 2004/2005, 2007/2008, 2009/2010 and 2010/2011 (Rex et al., 2006; Harris et al., 2010; Pitts et al., 2011; Khosrawi

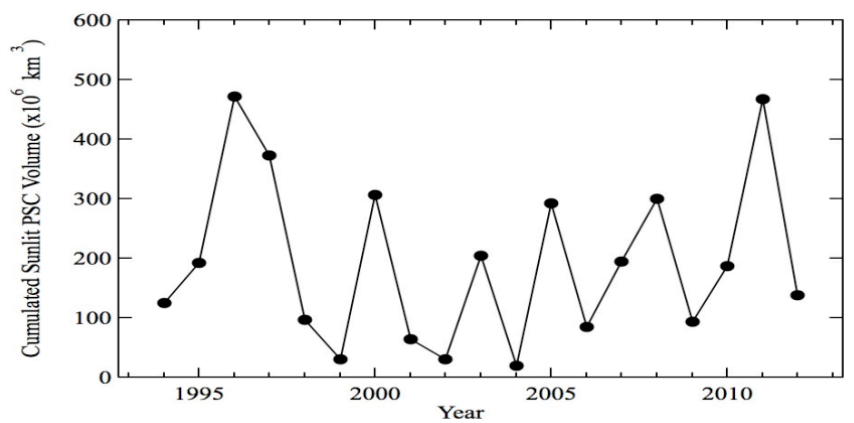

Fig. 11. Cumulated sunlit VPSC between 400-675 K since 1994. The PSC volume in 2011 was of same order of magnitude to that of 1996.

et al., 2011; Arnone et al., 2012 and references herein). The non-zero $\mathrm{NO}_{2}$ diurnal variation is coming from nondenitrified high-altitude layers above $25 \mathrm{~km}$, as observed for example from balloon measurements in the vortex in January during the cold winter of 1992 by Pommereau and Piquard (1994). But less frequent is the extension of the denitrification until early March such as in 1996, 1997, 2000 and 2011. And even less frequent is its persistence, that is, the absence of renitrification until mid-March in 2000 and 2011 only, the last being the record year. The proposed explanation for that is in the unusual strength of the vortex in 2011, shown by the maximum PV gradient larger than in all previous years (Fig. 10) as pointed out by Manney et al. (2011). Such strength prevented renitrification by import of $\mathrm{NO}_{\mathrm{y}}$ and $\mathrm{HNO}_{3}$ rich air masses from the outside of the vortex as frequently observed in the Arctic after minor warming episodes and subsequent elongation and reformation of the vortex. However, as for the ozone loss in Fig. 7 or denitrification in Fig. 9, there is no sign of trend in the vortex strength since 1994, but high inter-annual variability only.

\subsection{Relation between ozone loss and PSC volume}

The integrated PSC volume indicative of PSC vertical extension and duration has been proposed as proxy of total ozone loss each year (Rex et al., 2004, 2006, Harris et al., 2010). Displayed in Fig. 11 is the yearly sunlit $V_{\text {PSC }}$ between 400-675 K since 1994 derived from ERA-Interim temperatures. The sunlit PSC volume was not larger in 2011 than in 1996. In that case there is also no sign of trend, but of high variability. Figure 12 shows the relationship between SAOZ total column losses and integrated $V_{\text {PSC }}$ between 400-675 K for the whole vortex on the left and sunlit only on the right. The non-zero intercept is consistent with a pure gas-phase ozone loss in the absence of PSC as in 1999 and 2002. Although the ozone loss shows better correlation with sunlit $V_{\text {PSC }}(0.95)$ than with total $V_{\text {PSC }}(0.88)$, this proxy alone cannot explain the larger ozone loss in 2011. Another parameter is required: the state of denitrification-controlling chlorine 

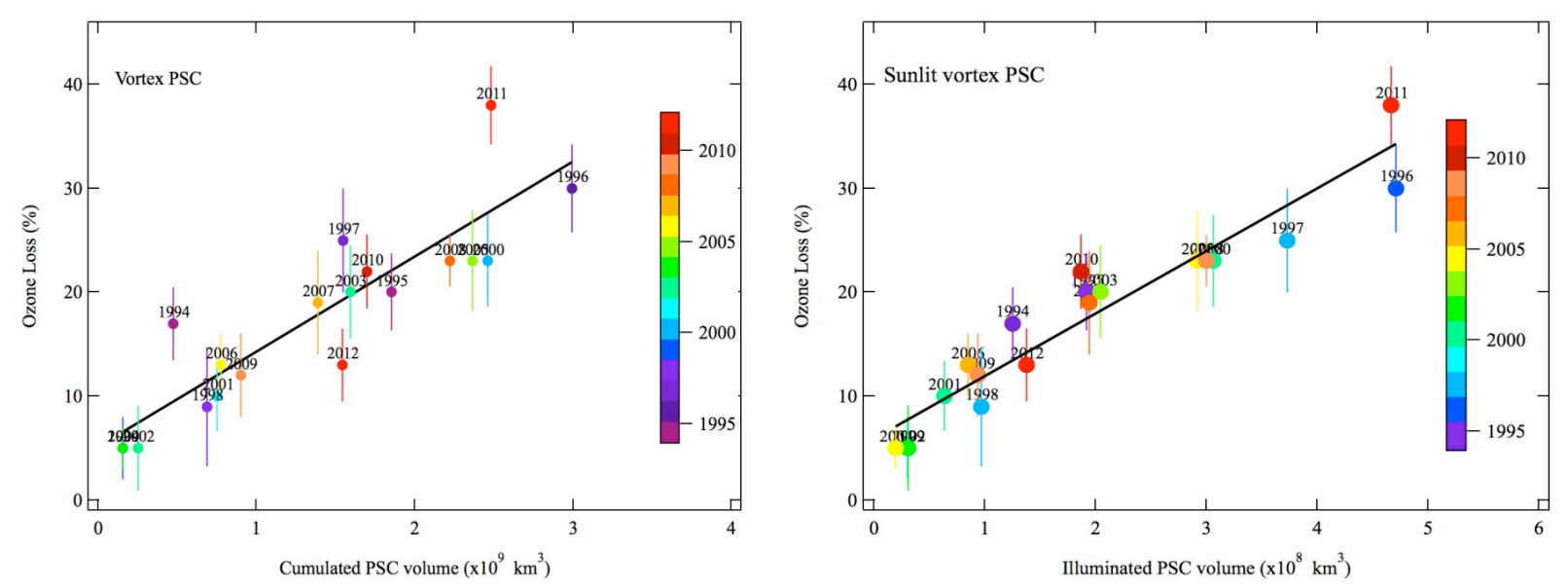

Fig. 12. Relationship between SAOZ total column ozone loss and $V_{\mathrm{PSC}}$ between $400-675 \mathrm{~K}$ calculated from ERA-Interim temperatures. Left: $V_{\mathrm{PSC}}$ inside vortex; right: sunlit $V_{\mathrm{PSC}}$ only, indicative of potential chorine activation. The selection of sunlit $V_{\mathrm{PSC}}$ instead of total $V_{\mathrm{PSC}}$ increases the correlation from 0.88 to 0.95 . Although $V_{\mathrm{PSC}}$ was similar or larger in 1996 than in 2011, the ozone loss was smaller, implying that another proxy, the state of denitrification, is controling its amplitude.

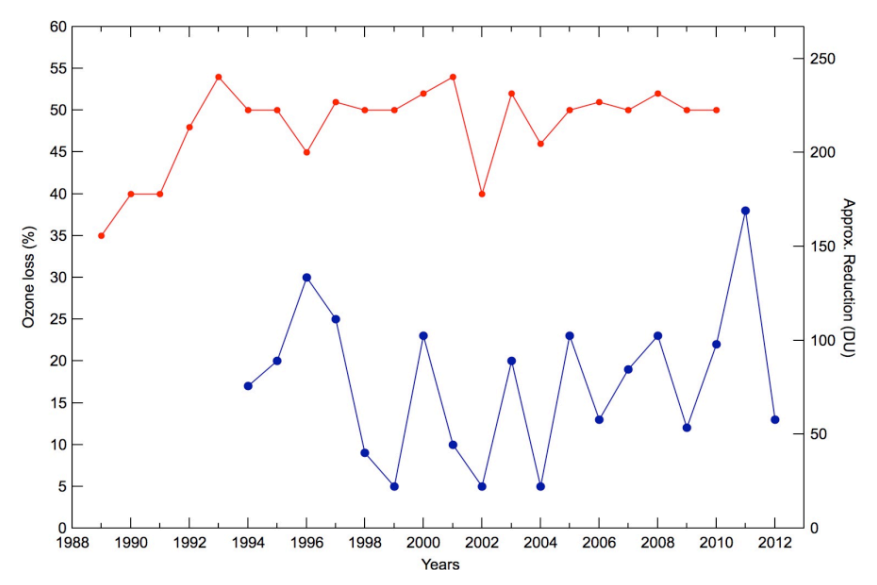

Fig. 13. Total ozone losses calculated between 1989-2012 from the SAOZ network and the passive ozone technique in the Arctic (blue) and the Antarctic (red, adapted from Kuttippurath et al., 2010). The amplitude of the 2011 Arctic depletion was similar to that of the 2002 Antarctic ozone hole.

deactivation, far larger in 2011 than in other years such as 1996, 1997, high in $V_{\mathrm{PSC}}$ or sunlit $V_{\mathrm{PSC}}$.

\section{Comparison with the Antarctic}

The yearly total ozone loss in the Arctic is compared in Fig. 13 to that of the Antarctic, calculated from groundbased and satellite data with the same passive ozone method (adapted from Kuttippurath et al., 2010). Figure 13 suggests that for the pre-1992 period the amplitude of the Antarctic ozone hole was comparable to the Arctic in 2011. The amplitude of the 2011 Arctic depletion is of the same order of magnitude to that of the early warming winter of 2002 in the
Antarctic when the depletion stopped during the second half of September (Stolarski et al., 2005), the equivalent of the second half of March in the north, implying a loss process identical in the Arctic in 2011 to that observed every year in the Antarctic. This is confirmed by the similarity of the loss rate of $0.7 \%$ day $^{-1}$ derived by Kuttippurath et al. (2010) in the deeply denitrified Antarctic ozone hole after the formation of high-altitude PSCs in the early winter in June and July (Pitts et al., 2007). The full denitrification is a typical feature of the $\mathrm{SAOZ} \mathrm{NO} 2$ columns measurements in the deeply denitrified Antarctic vortex, where a diurnal variation was never observed in the vortex before the final warming.

The similarity of the ozone loss rate in the Arctic in 2011 with that occurring in the Antarctic over the last $20 \mathrm{yr}$ indicates that for the first time, the process responsible was identical. A 15-day extension of the cold period until early April in the Arctic in 2011 would have been enough to reach an ozone hole amplitude similar to that of the Antarctic.

\section{Conclusions}

The reason for the unprecedented ozone loss in the Arctic in 2011 has been explored from the total ozone and $\mathrm{NO}_{2}$ measurements of the eight SAOZ/NDACC UV-Vis stations deployed in the Arctic. The ozone depletion in the polar vortex reached $38 \%$ (approx. $170 \mathrm{DU}$ ) in late March, larger than the $30 \%$ of the previous Arctic record in 1996. Among the $38 \%$ total reduction, $12 \%(50 \mathrm{DU})$ are attributed to gas phase $\mathrm{NO}_{\mathrm{x}}$ photochemical cycles. The cause of this 2011 record is shown to originate from an unusually $\mathrm{NO}_{\mathrm{x}}$-depleted vortex until late March, resulting in a total ozone loss rate of $0.7 \% \mathrm{~d}^{-1}$ never seen before in the Arctic but similar to that observed every year over the Antarctic. The cause of both the duration of the winter and the high loss rate is attributed 
to an unprecedented strength of the vortex, which prevented partial chlorine deactivation by $\mathrm{NO}_{\mathrm{y}}$ and $\mathrm{HNO}_{3}$ import from the outside, as observed every year in the Arctic (in contrast to the Antarctic) where the vortex remains generally isolated during the entire winter. The total ozone reduction at the end of the PSC period on 20 March was identical to that of the 2002 Antarctic winter, which ended around 20 September. There is no sign of trend since 1994, neither in PSC volume, amplitude of denitrification in the early winter, renoxification of the vortex nor in total ozone depletion, but of high interannual variability. From the SAOZ observations there is no indication suggesting that the Arctic ozone loss has amplified or reduced since 1994. The only intriguing question is the reason for the unusual vortex strength in 2011 and if it could repeat in the future. This strength will highly depend on the further evolution of the winter Arctic stratospheric temperature. If warming in the future (as predicted by most chemistry-climate models because of the increased wave activity) compensates the cooling resulting from the increased levels of greenhouse gases (Sinnhuber et al., 2011; WMO, 2011), the extreme 2011 ozone loss will remain a unique event and will not repeat. But the uncertainty on the further evolution of the temperature of the Arctic winter stratosphere does not allow for a prediction that it will not happen again in the future.

Acknowledgements. The authors are indebted to the personnel operating the SAOZ/NDACC stations and the ETHER data centre http://ether.ipsl.jussieu.fr/ for providing ECMWF analyses and reanalyses. The SAOZ measurements at Eureka were made with the support of the Canadian Network for the Detection of Atmospheric Change (CANDAC), led by James R. Drummond, and as part of the Canadian Arctic ACE Validation Campaigns, co-led by Kaley A. Walker and Kimberly Strong and funded by the Canadian Space Agency, Environment Canada, the Natural Sciences and Engineering Research Council, and the Northern Scientific Training Program. The SAOZ data are available at http://www.ndsc.ncep.noaa.gov/. The research was supported by the NDACC French programme funded by the CNRS Institut National des Sciences de l'Univers (INSU), the Centre National d'Etudes Spatiales (CNES) and the polar Institute Paul Emile Victor (IPEV), which are gratefully acknowledged.

Edited by: T. von Clarmann

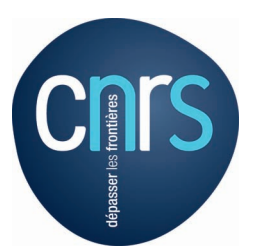

The publication of this article is financed by CNRS-INSU.

\section{References}

Adams, C., Strong, K., Zhao, X., Bassford, M. R., Chipperfield, M. P., Daffer, W. H., Drummond, J. R., Farahani, E., Feng, W., Fraser, A., Goutail, F., Manney, G. L., McLinden, Pazmino, A. Rex, M., and Walker, K. A.: Severe 2011 ozone depletion assessed with 11 years of ozone, $\mathrm{NO}_{2}$, and $\mathrm{OClO}$ measurements at $80^{\circ} \mathrm{N}$, Geophys. Res. Lett., 39, L05806, doi:10.1029/2011GL050478, 2012.

Arnone, E., Castelli, E., Papandrea, E., Carlotti, M., and Dinelli, B. M.: Extreme ozone depletion in the 2010-2011 Arctic winter stratosphere as observed by MIPAS/ENVISAT using a 2D tomographic approach, Atmos. Chem. Phys., 12, 9149-9165, doi:10.5194/acp-12-9149-2012, 2012.

Denis. L., Pommereau, J.-P., Lefèvre, F., Goutail, F., Knudsen, B., and Letrenne, G.: Ozone loss and $\mathrm{NO}_{2}$ recovery during the winter and spring 1997 as observed from long duration balloons flights in the vortex, Proc. 5th European Ozone Workshop, European Commission Air Pollution Report 73, 4425-428, 2000.

Goutail, F., Pommereau, J.-P., Phillips, C., Deniel, C., Sarkissian, A., Lefèvre, F., Kyro, E., Rummukainen, M., Eriksen, P., Andersen, S. B., Kaastadt Hoiskar, B.-A., Braathen, G., Dorohkov, V., and Khattatov, V. U.: Total Ozone depletion in the Arctic during the winters of 1993-94 and 1994-95, J. Atmos. Chem., 32, 1-34, 1999.

Goutail, F., Pommereau, J.-P., Lefèvre, F., van Roozendael, M., Andersen, S. B., Kåstad Høiskar, B.-A., Dorokhov, V., Kyrö, E., Chipperfield, M. P., and Feng, W.: Early unusual ozone loss during the Arctic winter 2002/2003 compared to other winters, Atmos. Chem. Phys., 5, 665-677, doi:10.5194/acp-5-665-2005, 2005.

Hanson, D. and Mauersberger, K.: Laboratory studies of the nitric acid trihydrate: implication for the south polar stratosphere, Geophys. Res. Lett., 15, 855-858, 1988.

Harris, N. R. P., Lehmann, R., Rex, M., and von der Gathen, P.: A closer look at Arctic ozone loss and polar stratospheric clouds, Atmos. Chem. Phys., 10, 8499-8510, doi:10.5194/acp-10-84992010, 2010.

Hauchecorne, A., Godin, S., Marchand, M., Heese, B., and Souprayen, C.: Quantification of the transport of chemical constituents from the polar vortex to midlatitudes in the lower stratosphere using the high-resolution advection model MIMOSA and effective diffusivity, J. Geophys. Res., 107, 8289, doi:10.1029/2001JD000491, 2002.

Hendrick, F., Pommereau, J.-P., Goutail, F., Evans, R. D., Ionov, D., Pazmino, A., Kyrö, E., Held, G., Eriksen, P., Dorokhov, V., Gil, M., and Van Roozendael, M.: NDACC/SAOZ UV-visible total ozone measurements: improved retrieval and comparison with correlative ground-based and satellite observations, Atmos. Chem. Phys., 11, 5975-5995, doi:10.5194/acp-11-5975-2011, 2011.

Khosrawi, F., Urban, J., Pitts, M. C., Voelger, P., Achtert, P., Kaphlanov, M., Santee, M. L., Manney, G. L., Murtagh, D., and Fricke, K.-H.: Denitrification and polar stratospheric cloud formation during the Arctic winter 2009/2010, Atmos. Chem. Phys., 11, 8471-8487, doi:10.5194/acp-11-8471-2011, 2011.

Knudsen, B. M., Pommereau, J.-P., Garnier, A., Nunes Pinharanda, M., Denis, L., Newman, P. A., Letrenne, G., and Durand, M.: Accuracy of analysed stratospheric temperatures in the winter Arctic vortex from infrared Montgolfier long-duration bal- 
loon flights. 2. Results, J. Geophys. Res., 107, 4316-4330, doi:10.1029/2001JD001379, 2002.

Kuttippurath, J., Goutail, F., Pommereau, J.-P., Lefèvre, F., Roscoe, H. K., Pazmiño, A., Feng, W., Chipperfield, M. P., and GodinBeekmann, S.: Estimation of Antarctic ozone loss from groundbased total column measurements, Atmos. Chem. Phys., 10, 6569-6581, doi:10.5194/acp-10-6569-2010, 2010.

Kuttippurath, J., Godin-Beekmann, S., Lefèvre, F., Nikulin, G., Santee, M. L., and Froidevaux, L.: Record-breaking ozone loss in the Arctic winter 2010/2011: comparison with 1996/1997, Atmos. Chem. Phys., 12, 7073-7085, doi:10.5194/acp-12-70732012, 2012.

Lefevre, F., Brasseur, G. P., Folkins, I., Smith, A. K., and Simon, P.: Chemistry of the 1991-92 stratospheric winter: three dimensional model simulations, J. Geophys. Res., 99, 8183-8195, 1994.

Lindenmaier, R., Strong, K., Batchelor, R. L., Chipperfield, M. P., Daffer, W. H., Drummond, J. R., Duck, T. J., Fast, H., Feng, W., Fogal, P. F., Kolonjari, F., Manney, G. L., Manson, A., Meek, C., Mittermeier, R. L., Nott, G. J., Perro, C., and Walker, K. A.: Unusually low ozone, $\mathrm{HCl}$, and $\mathrm{HNO}_{3}$ column measurements at Eureka, Canada during winter/spring 2011, Atmos. Chem. Phys., 12, 3821-3835, doi:10.5194/acp-12-3821-2012, 2012.

Manney, G., Santee, M. L., Rex, M., Livesey, N. J., Pitts, M. C., Veefkind, P., Nash, R. R., Wohltmann, I., Lehmann, R., Froidevaux, L., Poole, L. R., Schoeberl, M. R., Haffner, D. P., Davies, J., Dorokhov, V., Gernandt, H., Johnson, B., Kivi, R., Kyr o, E., Larsen, N., Levelt, P. F., Makshtas, A., McElroy, C. T., Nakajima, H., Parrondo, M. C., Tarasick, D. W., von der Gathen, P., Walker, P. K. A., and Zinoviev, N. S.: Unprecedented Arctic ozone loss in 2011, Arctic winter 2010/2011 at the brink of an ozone hole, Nature, 478, 469-475, doi:10.1038/nature10556, 2011.

Nash, E. R., Newman, P. A., Rosenfield, J. E., and Schoeberl, M. R.: An objective determination of the polar vortex using Ertel's potential vorticity, J. Geophys. Res., 101, 9471-9478, 1996.

Pitts, M. C., Thomason, L. W., Poole, L. R., and Winker, D. M.: Characterization of Polar Stratospheric Clouds with spaceborne lidar: CALIPSO and the 2006 Antarctic season, Atmos. Chem. Phys., 7, 5207-5228, doi:10.5194/acp-7-5207-2007, 2007.

Pitts, M. C., Poole, L. R., Dörnbrack, A., and Thomason, L. W.: The 2009-2010 Arctic polar stratospheric cloud season: a CALIPSO perspective, Atmos. Chem. Phys., 11, 2161-2177, doi:10.5194/acp-11-2161-2011, 2011.

Pommereau, J.-P. and Goutail, F.: $\mathrm{O}_{3}$ and $\mathrm{NO}_{2}$ Ground-Based Measurements by Visible Spectrometry during Arctic Winter and Spring 1988, Geophys. Res. Lett., 15, 891-894, 1988.

Pommereau, J. P. and Piquard, J.: Ozone, Nitrogen dioxide and Aerosol vertical distributions by UV-visible solar occultation from balloons, Geophys. Res. Lett, 21, 1227-1230, 1994.

Pommereau, J.-P., Garnier, A., Knudsen, B. M., Letrenne, G., Durand, M., Csersnjes, P., Nunes-Pinharanda, M., Denis, L., Vial, F., Hertzog, A., Cairo, F.: Accuracy of Analysed Stratospheric Temperatures in the Winter Arctic Vortex from Infra Red Montgolfier Long Duration Balloon Flights. Part I: Measurements, J. Geophys. Res., 107, 8260-8277, doi:10.1029/2001JD001329, 2002.
Rex, M., Salawitch, R. J., von der Gathen, P., Harris, N. R. P., Chipperfield, M. P., and Naujokat, B.: Arctic ozone loss and climate change, Geophys. Res. Lett., 31, L04116, doi:10.1029/2003GL018844, 2004.

Rex, M., Salawitch, R. J., Deckelmann, H., von der Gathen, P., Harris, N. R. P., Chipperfield, M. P., Naujokat, B., Reimer, E., Allaart, M., Andersen, S. B., Bevilacqua, R., Braathen, G. O., Claude, H., Davies, J., De Backer, H., Dier, H., Dorokov, V., Fast, H., Gerding, M., Godin-Beekmann, S., Hoppel, K., Johnson, B., Kyro, E., Litynska, Z., Moore, D., Nakane, H., Parrondo, M. C., Risley, A. D., Skrivankova, P., Stubi, R., Viatte, P., Yushkov, V., and Zerefos, C.: Arctic winter 2005: Implications for stratospheric ozone loss and climate change, Geophys. Res. Lett., 33, L23808, doi:10.1029/2006GL026731, 2006.

Sander, S. P., Abbatt, J., Barker, J. R., Burkholder, J. B., Friedl, R. R., Golden, D. M., Huie, R. E., Kolb, C. E., Kurylo, M. J., Moortgat, G. K., Orkin, V. L., and Wine, P. H.: Chemical Kinetics and Photochemical Data for Use in Atmospheric Studies, Evaluation No. 17, JPL Publication 10-6, Jet Propulsion Laboratory, Pasadena, 2011

Simmons, A. J., Uppala, S. M., Dee, D., and Kobayashi, S.: ERA Interim: New ECMWF reanalysis products from 1989 onwards, ECMWF News Lett., 110, 25-35, 2006.

Sinnhuber, B.-M., Stiller, G., Ruhnke, R., von Clarmann, T., Kellmann, S., and Aschmann, J.: Arctic winter 2010/2011 at the brink of an ozone hole, Geophys. Res. Lett, 38, L24814, doi:10.1029/2011GL049784, 2011.

Stein, B., Wedekind, C., Wille, H., Immler, F., Müller, M., Wöste, L., del Guasta, M., Morandi, M., Stefanutti, L., Antonelli, A., Agostini, P., Rizi, V., Readelli, G., Mitev, V., Matthey, R., Kivi, R., and Kyrö, E.: Optical classification, existence temperatures, and coexistence of different stratospheric cloud types, J. Geophys. Res., 1042, 23983-23994, doi:10.1029/1999JD900064, 1999.

Stolarski, R. S., McPeters, R. D., and Newman, P. A.: The ozone hole of 2002 as measured by TOMS, J. Atmos. Sci., 62, 716$720,2005$.

WMO (World Meteorological Organization): Scientific assessment of ozone depletion: 2006, Global Ozone Research and Monitoring Project-Report 50, Geneva, Switzerland, 2007.

WMO (World Meteorological Organisation): Scientific assessment of ozone depletion: 2010, Global Ozone Research and Monitoring Project, Report 52, 516 pp., Geneva, Switzerland, 2011. 